\title{
Micro-hardness of acrylic resin utilized for provisional crowns: Effect of different polymerization techniques and $\mathrm{pH}$-Cycling.
}

Avaliação da microdureza de resina acrílica para coroas provisórias: Efeito de diferentes técnicas de processamento e ciclos dinâmicos de ph.

Cesar Augusto Zanlorenzi NICODEMO ${ }^{1}$, Carlos Eduardo Edwards REZENDE ${ }^{1}$, Rafael Tobias MORETTI-NETO ${ }^{2}$, José Henrique RUBO ${ }^{1}$

1 - Bauru School of Dentistry - University of São Paulo - Bauru - SP - Brazil.

2 - Alfenas Federal University - Alfenas - MG - Brazil.

\section{ABSTRACT}

Objective: This study aimed at evaluating the micro-hardness of an acrylic resin used for provisional crowns. Materials and methods: Five different processing techniques (direct and indirect) were assessed: (I) auto polymerizing resin in sandy stage; (II) auto polymerizing resin in plastic stage; (III) bead-brush technique; (IV) auto polymerizing resin under pressure; (V) heatcured acrylic resin under pressure. Five specimens were made for each test group. For the initial micro-hardness test, the specimens were immersed in deionized water for 48 hours. For the analysis of the final micro-hardness, the specimens were subjected to $\mathrm{pH}$-cycling to simulate the changes in the $\mathrm{pH}$ level which occur in the oral cavity. Results: Tests revealed that the micro-hardness was decreased after the pH-cycling. However, no statistical difference was found among the different types of acrylic resin polymerization techniques. Conclusion: It was concluded that the micro-hardness is not directly related to the polymerization technique for making provisional crowns.

\section{KEYWORDS}

Acrylic resins; Dental crowns; Dental prosthesis; Temporary dental restoration.

\section{RESUMO}

Objetivo: Avaliou-se a dureza superficial de uma resina acrílica (PMMA) utilizada para a confecção de coroas provisórias. Material e Métodos: Cinco diferentes técnicas de processamento (Direta e Indireta) para polimerização da resina foram testadas: I - autopolimerização após mistura (pó + líquido) em pote dappen e inserção em matriz de silicona na fase arenosa; II - autopolimerização após mistura em pote dappen com inserção em matriz de silicona na fase plástica; III - autopolimerização utilizando a técnica do pincel; IV - autopolimerização sob pressão em matriz de silicona; $\mathrm{V}$ - polimerização térmica utilizando líquido de polimerização rápida em mufla. Foram confeccionados cinco corpos-de-prova para cada grupo. Para o teste de microdureza inicial os espécimes foram imersos em água deionizada por 48 horas. Para a análise da dureza final, os espécimes foram submetidos a ciclos dinâmicos de $\mathrm{pH}$, para simular a variação de $\mathrm{pH}$ ocorrida na cavidade oral. Resultados: Os testes revelaram que houve diminuição da dureza do material após a ciclagem ácida, porém não foi verificada diferença estatística entre os diferentes tipos de processamento da resina acrílica. Conclusão: Concluiu-se que a microdureza não está relacionada diretamente com a técnica de confecção dos provisórios.

\section{PALAVRAS-CHAVE}

Resinas acrílicas; Coroas dentárias; Prótese dentária; Prótese parcial temporária.

professional to foresee the success of the final restoration in its mechanical, aesthetic and functional aspects [1,2]. Provisional crowns work as a diagnostic device [3] and allow for the correction of the occlusal plane and vertical 
dimension [2], establishment of occlusal guidance and posterior occlusal contacts, evaluation and conditioning of the gingival tissues and prediction of the shape, size and color of the restauration [4].

The most common material used in provisional crowns is the auto-polymerizing acrylic resins, more precisely poly-methyl methacrylate (PMMA). Because of the longterm use of provisional restorations, superficial wear can occur due to tooth-brush abrasion [5] and parafunction attrition [2]. Only the longterm use of provisional crowns is a determinant factor to promote superficial wear [6]. The dietary solvents are also an important factor on the superficial wear of the provisional restorations [7].

Provisional crowns can be made either chair-side (direct technique) or on a cast model with the help of a dental laboratory (indirect technique) [3]. The option for one of these techniques is based on factors like the type or the extension of the prosthesis and the expected treatment longevity. The polymerization technique can modify the acrylic resin properties $[8,9]$. It may compromise the quality of the provisional crowns and can contribute to the treatment failure $[1,3,10]$. Thus, it is important to evaluate, among the other properties, the superficial hardness of the acrylic resin when submitted to different processing protocols.

Superficial micro-hardness can be used for density indication, so that denser materials should have more resistance to superficial wear $[2,11]$. Thus, evaluating the micro-hardness of the acrylic resins signifies evaluating this material's capacity of maintaining the diagnostic elements provided by the treatment up to the definitive prosthesis cementation. There are few studies regarding the acrylic resin micro-hardness modification, mainly on the different techniques of resin processing. Thus, the aim of this study is to verify this micro-hardness alteration while varying the different technique.

\section{MATERIAL AND METHODS}

The present study consisted of two stages: 1st - evaluation of the micro-hardness considering five different techniques for provisional crowns production; 2nd - evaluation of the final microhardness after $\mathrm{pH}$-Cycling.

For the first stage, 25 specimens were made in acrylic resin (Dencor ${ }^{\circledR}$ - Artigos Odontológicos Clássico LTDA, São Paulo - SP, Brazil), which is an auto-polymerizing PMMA for provisional crowns fabrication. The specimens consisted of a disc with $2 \mathrm{~cm}$ of diameter and $3 \mathrm{~mm}$ of thickness and were standardized from an impression made in silicone (Zetalabor ${ }^{\circledR}$ Zhermack, Badia Polesine/ RO - Italy) which was used as a matrix. These specimens were equally divided into five different groups which were composed of different techniques of acrylic resin processing.

Except for group III (bead-brush technique), the mixing proportion used was: $1.50 \mathrm{~g}$ of polymer, measured by weight in a high precision scale (Sauter $\AA$, model $\mathrm{K}$ 1200 , Switzerland) and $0.70 \mathrm{~mL}$ of monomer, measured by volume with a pipette (Pyrobras ${ }^{\circledR}$ ) i.e equivalent volume ratio $3: 1$ as indicated by the manufacturer. The liquid and the powder were dispensed in a Dappen dish and smoothly mixed for five seconds.

Groups:

- Group I: for this group the liquid was saturated with the powder to obtain a smooth texture. The mold was filled with the acrylic resin immediately after saturation, in its sandy stage.

- Group II: the liquid was saturated with the powder to obtain a smooth texture. The resin was allowed to reach its plastic stage (1.5 to 2 minutes after mixing) keeping a glass slab on top of the Dappen dish to avoid excessive monomer evaporation. Then, the acrylic resin was inserted into the mold with a spatula. 
- Group III: the acrylic monomer and polymer were dispensed in separate Dappen dishes in order to use the bead-brush technique. The tip of the brush was moistened by the liquid and put in contact with the powder. The silicone mold was continually filled with the resin until completely full.

- Group IV: the specimens were made by manipulating the acrylic resin in a Dappen dish and pouring it in the silicone mold when the resin was in the plastic stage. This mold was placed against a plaster platform and stabilized with rubber bands. The mold and plaster platform set was immersed in water under pressure $(3 \times 105 \mathrm{~N} / \mathrm{m} 2)$ at $70^{\circ} \mathrm{C}$ for 15 minutes.

- Group V: five wax blocks were flasked with dental stone (Durone IV, Dentsply, Rio de Janeiro, Brazil), according to the conventional procedures. After the stone was set, the wax was removed and the acrylic resin was manipulated. When the plastic stage was obtained (1.5 to 2 minutes after saturation in Dappen dish), the resin was inserted into the flasks. The flasks were then taken to a hydraulic press and immersed in water under pressure (3 x 105 $\mathrm{N} / \mathrm{m}^{2}$ ) and heated to $70^{\circ} \mathrm{C}$ for 15 minutes. Deflasking was performed by routine laboratory procedure.

The specimens were finished in a lathe (APL 4, Arotec, Cotia, Brazil) using a sequence of 320, 600 and 1200 grit wet sandpaper. This system allows the automatic polishing of 6 specimens simultaneously. The final polishing was made by a felt disc impregnated with 0.3 $\mu \mathrm{m}$ alumina solution for 4 minutes in high speed and a load of $215 \mathrm{~g}$. The goal of this stage was to standardize the surfaces of the specimens before the micro-hardness measurements.

\section{Digital microscopy analysis}

To test the initial micro-hardness, the specimens were embedded in deionized water for $48 \mathrm{~h}$ and then dried at $37^{\circ} \mathrm{C}$ for $24 \mathrm{~h}$ in a stove. After this procedure, the Knoop micro- hardness measurements were made with a microdurometer (HMV-2000/ Shimadzu Corporation, Japan), which was linked to a computer with a specific software used for the image analysis (Cams-Wins-New Age Industries/ USA). The microdurometer has a diamond tip which penetrates the specimen with a $0.025 \mathrm{Kg}$ load for 10 seconds and a 10x objective lens was used to read the microhardness parameters (Fig 1).

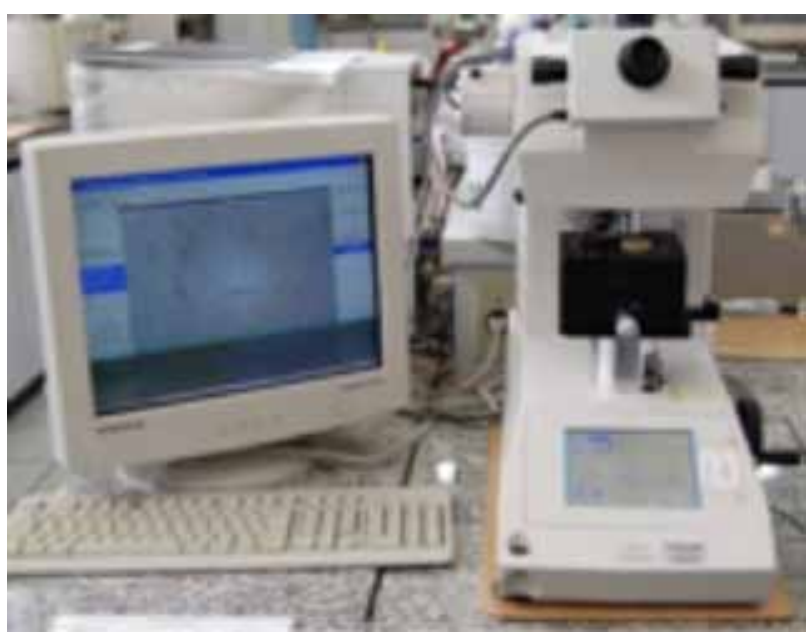

Figure 1- Microdurometer linked to a Desktop Computer.

When the microdurometer is activated, the diamond tip presses the specimen surface generating a lozenge shaped geometric figure which can be visualized by the contrast between the impression and the specimen surface. The lozenge allows for the determination of the superficial micro-hardness by the measurement of its major diagonal. This value is applied to a mathematical equation to obtain the results. The microdurometer used in the experiment automatically performs calculations, from two dotted marks overlapping to the sharp corners of the lozenge. (Fig 2)

The specimen's surface elected to the microhardness reading was divided into quadrants and one indentation was made in the center of each quadrant for all the specimens. On the other surface, markings were performed to allow the identification of the specimens during and after the $\mathrm{pH}$ cycling procedures. (Fig 3) 


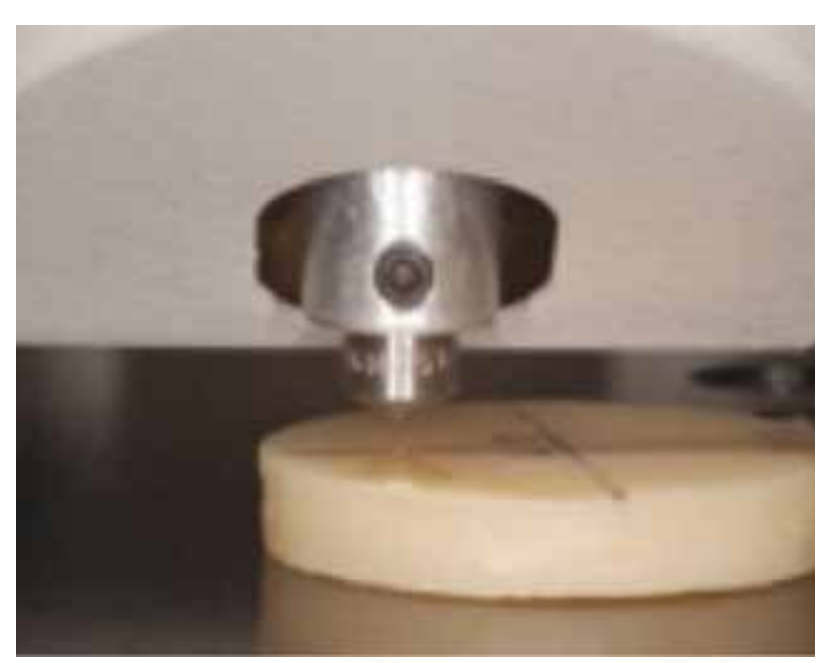

Figure 2 - Microdurometer diamond tip penetrating the specimen surface. The specimens were divided in quadrants.

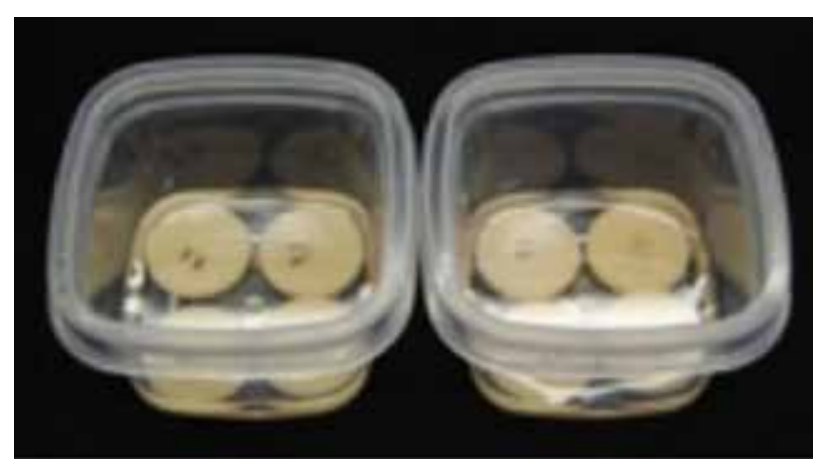

Figure 3 - Specimens immersed in artificial saliva.

\section{pH Cycling}

In the second stage, the final micro-hardness of the specimens was analyzed after its submission to a pH dynamic cycling, according to the method proposed by Featherstone et al (1990) [12] and modified by Carvalho and Cury (1999) [13], to simulate the change of acidity occurring in the oral cavity. The $\mathrm{pH}$ cycling corresponded to the specimen's immersion in an acid solution for six hours and intercalated with artificial saliva for 18h during 15 days (Fig 3).

The acidic solution consisted of $2 \mathrm{mM}$ calcium chloride and $2.0 \mathrm{mM}$ potassium phosphate in a solution of $75 \mathrm{mM}$ acetic acid at $\mathrm{pH}$ 4.3. The artificial saliva consisted of $1.5 \mathrm{mM}$ calcium chloride, $0.9 \mathrm{mM}$ potassium phosphate and $150 \mathrm{mM}$ Potassium Chloride in a $2 \mathrm{mM}$ solution of hydroxymethyl-aminomethane at $\mathrm{pH}$ 7.0.

\section{Statistical Analysis}

After obtaining the data, the mean values for the micro-hardness, before and after the $\mathrm{pH}$ cycling, was calculated to classify the hardness reduction that occurred for the different groups. These values were grouped and compared with the 2-way variance analysis (ANOVA) for the variables processing technique and $\mathrm{pH}$ cycling and the Tukey Test was used for the comparison among the groups.

\section{RESULTS}

The statistical analysis revealed a significant difference before and after the $\mathrm{pH}$ cycling. The Knoop micro-hardness test measurements revealed a reduction in the superficial hardness after the $\mathrm{pH}$ cycling for all the evaluated specimens (Table 1).

Regarding the acrylic resin processing technique, there was no statistical significant difference found among the studied groups, thus, the technique used to fabricate temporary crowns does not influence the superficial hardness. The interaction between the variables included in this experiment was verified with the 2-way Anova test, adopting a significance level of $\mathrm{p}<0.05$. No statistical significant difference was found for the interaction of the studied variables (Table 2).

Table 1 - Mean and standard deviation (SD) values of microhardness for the different methods of processing before and after the $\mathrm{pH}$ cycling

\begin{tabular}{|ccc|}
\hline & Before pH Cycling & After pH cycling \\
\hline Groups & (Mean \pm SD) & (Mean \pm SD) \\
\hline I & $14.06 \pm 0.61 \mathrm{~A}$ & $13.03 \pm 0.48 \mathrm{~B}$ \\
\hline II & $13.47 \pm 0.48 \mathrm{~A}$ & $12.71 \pm 0.44 \mathrm{~B}$ \\
\hline III & $14.12 \pm 0.65 \mathrm{~A}$ & $12.93 \pm 0.34 \mathrm{~B}$ \\
\hline IV & $13.73 \pm 0.87 \mathrm{~A}$ & $12.65 \pm 0.35 \mathrm{~B}$ \\
V & $13.48 \pm 1.01 \mathrm{~A}$ & $12.73 \pm 0.29 \mathrm{~B}$ \\
\hline
\end{tabular}

* Different letters indicate statistical significance. 
Table 2 - Variances analysis (ANOVA) between the tested groups and phases (before and after de pH Cycling) and the interaction between both factors

$\begin{array}{ccccccc} & \text { DfEffect } & \text { MSEffect } & \text { DfError } & \text { MSError } & \text { F } & \text { P } \\ \text { Group } & 4 & 0.506593 & 20 & 0.326566 & 1.551273 & \mathbf{0 . 2 2 6} \\ \text { Phase } & 1 & 11.57767 & 20 & 0.384614 & 30.10206 & \mathbf{0 . 0 0 0 *} \\ \text { Interaction } & 4 & 0.096787 & 20 & 0.384614 & 0.251647 & \mathbf{0 . 9 0 5}\end{array}$

* Statistical significant difference. $(p \ll 0.05)$

\section{DISCUSSION}

The term hardness is related to the resistance of the material for penetration [11]. Thus, the material hardness is determined by standardized tests that promote the penetration of a tip into this material with the use of a specific instrument known as a durometer. For the analysis of the polymeric materials, the Knoop hardness mensuration is more recommended $[2,14,15]$, because measures the major diagonal lozenge length which is maintained without dimensional changes, since the elastic recuperation and dimensional alterations occur on the shorter diagonal. Thus, the Knoop hardness value is virtually independent of the tested material ductility due to the action of tearing on the major diagonal [11].

Studies concerning the acrylic resin hardness often obtain the measurements after the immersion of the specimens in distilled water, disinfectant solutions [16] or alcohol [14]. However, the use of these solutions does not simulate the oral environment dynamics, which is characterized by constant variations in the bacterial biofilm's pH levels [13].

According to Cate (1990) [17], the $\mathrm{pH}$ variations in the oral environment are due to the bacterial biofilms action on the consumed fermentable carbohydrates (fast reduction of the $\mathrm{pH}$ levels) and to the saliva's buffering capacity (gradual elevation of the pH levels), characterizing the deremineralization phenomena. Throughout the day, this phenomenon results in a series of reductions in the $\mathrm{pH}$ levels, interspersed with resting periods. The simulation of this $\mathrm{pH}$ variation in the oral environment was made in vitro through the daily immersion of the specimens for limited periods in alternate solutions which promote demineralization and remineralization. The laboratory model of $\mathrm{pH}$ cycling allows for the in vitro analysis of the influence of de-remineralization process on the dental materials [17]. In this study, the $\mathrm{pH}$ cycling protocol first developed by Cate (1990) [17] for in vitro study and later modified by Carvalho and Cury (1999) [13], proved to be relevant for the evaluation of the $\mathrm{pH}$ dynamics on the acrylic resin hardness.

In the present study, all specimens showed a reduction of micro-hardness after the dietary simulating, in accordance with the studies of Yap et al (2004) [7] and Akova et al (2006) [18], who demonstrated a reduction in the micro-hardness after the storage of the specimens in heptane and ethanol solutions with different concentrations, in order to simulate the human diet. Some similarities were also found with other studies, in which there was a continuous decrease in hardness related to the storage time of specimens in water [16] and artificial saliva solution [6]. Conversely, the in vitro test performed by Whitman et al (1987) [14] stated that the conventional acrylic resin, IPN resin and Isosit stored in water had no significant variations between the initial and final hardness values, i.e., no loss of material hardness was found. However, when stored in ethanol, there was a reduction in the values, indicating a loss of hardness $[7,14,18]$.

The superficial hardness reduction can occur due to the water sorption phenomenon by polymeric materials. The water excess can cause a filler-matrix debonding [18]. In addition, the absence of cross-linked bifunctional acrylates in the methyl methacrylate based materials could further the softening effects of dietary acid solvents [7]. Another factor that 
may have influenced the hardness reduction for all the specimens is the presence of residual monomer, which adversely affects the mechanical properties due to a plasticizing effect that decreases the interchain forces and allowing the deformation to occur easily under load [9]. Regarding the storage of the specimens in artificial saliva, it may also contribute to the reduction of Knoop Hardness, because the saliva can act like water, causing the phenomenon of plasticizing and reduction of acrylic resin hardness [19].

In the present study, the five evaluated groups represent the main techniques for provisional crowns fabrication, in which two of them were made in laboratory (Groups IV and $\mathrm{V})$ and the others three are direct techniques (groups I,II and III). Based on studies evaluating other properties, such as roughness and porosity $[1,3]$, a statistical difference among these techniques was expected, however, this evidence was not demonstrated. Thus, based on the results obtained in this study, is not possible state that the hardness of an acrylic resin is related to the technique used for provisional crown fabrication, either laboratorial or directly made. This is in contradiction with the results of studies by Lee et al. (2002) [10] and Jo et al. (2011) [2], who found a higher microhardness for techniques in which the specimens were immersed in water under heating, as the specimens of the groups IV and V of the present study. This difference in results is probably attributed to the distinction of the methods used.

Evidently, only the observation of the micro-hardness is not sufficient to indicate a better technique for provisional crowns fabrication. The evaluation of others physical properties must be considered, such as roughness and porosity, wear after brushing simulation, flexural strength and others. Furthermore, the evaluation of these properties in different brands of acrylic resins and simulating other conditions present in the oral environment, like thermal variation, will enable the Dentist to more accurately display the technical and material that best suits his need.

\section{CONCLUSION}

In conclusion, the $\mathrm{pH}$ cycling reduces the hardness of the acrylic resin, independently of the processing technique, while the different processing techniques of the acrylic resin did not seem to influence the material hardness.

\section{ACKNOWLEDGEIMENTS}

The authors thank to FAPESP for the financial support (process $n^{\circ}$ 08/01381-0).

\section{REFERENCES}

1. Hiramatsu DA, Moretti Neto RT, Ferraz BFR, Porto VC, Rubo JH Roughness and porosity of provisional crowns. RPG. Revista de Pós-Graduação. 2011;18(1):108-12.

2. Jo LJ, Shenoy KK, Shetty S. Flexural strength and hardness of resins for interim fixed partial dentures. Indian J Dent Res 2011;22(1):71-6.

3. Nishida CL, Bianco VC, Hiramatsu DA, Moretti Neto RT, Rubo JH. Surface roughness analysis of acrylic resin for provisional crowns under different commercial brands. Full Dent Sci. 2011;2(5):56-62.

4. Gough M. A review of temporary crowns and bridges. Dent Update 1994;21(5):203-7.

5. Haselden CA, Hobkirk JA, Pearson GJ, Davies EH. A comparison between the wear resistance of three types of denture resin to three different dentifrices. J Oral Rehabil 1998;25(5):335-9.

6. Diaz-Arnold AM, Dunne JT, Jones AH. Microhardness of provisional fixed prosthodontic materials. J Prosthet Dent. 1999;82(5):525-8.

7. Yap AUJ, Mah MKS, Lye CPW, Loh PL. Influence of dietary simulating solvents on the hardness of provisional restorative materials. Dent Mat. 2004;20(4):370-6.

8. Bindo MJF, Nakamae AEM, Santos LB, Ishikawa KH, Guarnieri TC, Tamaki R. Study of the surface hardness and modulus of elasticity of conventional and microwave-cured acrylic resins. Braz Oral Res 2009:23(1):68-75.

9. Xediek Consani RL, Vieira ML, Mesquita MF, Sinhoreti MAC, Guiraldo RD, Nóbilo MAA. Effect of polymerization cycles on the linear dimensional change, hardness and impact strength of denture base acrylic resins. Minerva Stomatol 2012;61(6):272-81.

10. Lee SY, Lai YL, Hsu TS. Influence of polymerization conditions on monomer elution and microhardness of autopolymerized polymethyl methacrylate resin. Eur J Oral Sci. 2002;110(2):179-83.

11. Anusavice KJ. Phillip's Science of Dental Materials 11.ed. Rio de Janeiro: Elsevier, 2005.

12. Featherstone JD, Glena R, Shariati M, Shields CP. Dependence of in vitro demineralization of apatite and remineralization of dental enamel on fluoride concentration. J Dent Res. 1990 Feb;69 Spec No:620-5; discussion 634-6.

13. Carvalho AS, Cury JA. Fluoride release from some dental materials in different solutions. Oper Dent 1999;24(1):14-9.

14. Whitman DJ, McKinney JE, Hinman RW, Hesby RA, Pelleu GB Jr. In vitro wear rates of three types of commercial denture tooth materials. J Prosthet Dent 1987:57(2):243-6. 
15. Suzuki S. In vitro wear of nano-composite denture teeth. J Prosthodont 2004;13(4):238-43.

16. Pavarina AC, Vergani CE, Machado AL, Giampaolo ET, Teraoka MT. The effect of disinfectant solution on the hardness of acrylic resin denture teeth. J Oral Rehabil 2003;30(7):749-52.

17. Cate JMT. In vitro studies on the effects of fluoride on deremineralization. J Dent Res 1990;69(1):614-9.
18. Akova T, Ozkomur A, Uysal H. Effect of food-simulating liquids on the mechanical properties of provisional restorative materials. Dent Mat 2006, 22(12):1130-4.

19. Assunção WG, Gomes EA, Barão VAR, Barbosa DB, Delben JA, Tabata LF. Effect of storage in artificial saliva and thermal cycling on Knoop hardness of resin denture teeth. J Prosthodont Res 2010:54(3):123-7.

\section{Carlos Eduardo Edwards Rezende}

(Corresponding Author)

Alameda Octávio Pinheiro Brizolla, 